\title{
Antimicrobial activities of culturable microorganisms (actinomycetes and fungi) isolated from Chaabe Cave, Algeria
}

\author{
Larbi Belyagoubi ${ }^{1 *}$, Nabila Belyagoubi-Benhammou ${ }^{1}$, Valme Jurado ${ }^{2}$, Joëlle Dupont ${ }^{3}$, \\ Sandrine Lacoste ${ }^{3}$, Fatima Djebbah ${ }^{1}$, Fatima Z. Ounadjela ${ }^{1}$, Souad Benaissa ${ }^{1}$, Salim \\ Habi $^{1}$, Djamel E. Abdelouahid ${ }^{4}$, and Cesareo Saiz-Jimenez ${ }^{2}$ \\ ${ }^{1}$ Laboratoire des Produits Naturels (LAPRONA), Département de Biologie, Université Abou Bekr Belkaid, BP 119, Imama, Tlemcen, Algérie \\ ${ }^{2}$ Instituto de Recursos Naturales y Agrobiologia, IRNAS-CSIC, Avenida Reina Mercedes 10, 41012 Sevilla, Spain \\ ${ }^{3}$ Institut de Systématique, Évolution et Biodiversité, ISYEB - UMR 7205 - CNRS, MNHN, UPMC, EPHE, Muséum national d'histoire naturelle, \\ Sorbonne Universités, 57 rue Cuvier, CP39, 75231 Paris Cedex 5, France \\ ${ }^{4}$ Laboratoire de Microbiologie Appliquée à l'Agro-alimentaire, au biomédical et à l'Environnement, Université Abou Bekr Belkaid, BP 119, \\ Imama, Tlemcen, Algérie
}

\begin{abstract}
The discovery of new antibiotics and other bioactive microbial metabolites is a priority given the frequency of the emerging multi-drug resistant pathogenic microorganisms. Thus, scientists are searching for new antibiotics in microorganisms isolated from extreme habitats such as caves. In the present study, we aimed to perform the first analysis on culturable microorganisms in the Chaabe Cave (Algeria), and to test the antimicrobial activities of the isolates (Streptomyces spp. and Penicillium spp.). The potential for antimicrobial activity of 47 strains of actinomycetes and 23 strains of fungi were tested on Candida albicans, Staphylococcus aureus, Micrococcus luteus, Listeria monocytogenes, Bacillus subtilis, Escherichia coli, and Pseudomonas aeruginosa. The identification of the most active actinomycetes strains by $16 \mathrm{~S}$ rRNA gene sequence analysis revealed that these isolates were exclusively affiliated to the genus Streptomyces. On the other hand, the fungi were determined by phylogenetic analysis based on the ITS region or on the $\beta$ tubulin gene and were affiliated to the genera Readeriella, Cladosporium, Aspergillus, Penicillium, Beauveria, Alternaria, Rhizopus, and Rhizomucor. The strains showed strong inhibitory activity against pathogenic microorganisms and the diameters of the inhibition zones vary between 7.5 and $34 \mathrm{~mm}$ for Streptomyces strains, and between 6.5 and $19.50 \mathrm{~mm}$ for Penicillium strains. The data indicated that the majority $(72.86 \%)$ of the 70 isolates were active against at least one of the tested microorganisms. The production of nonpolyenic antifungal substances by active Streptomyces isolates was investigated using several criteria (antibacterial activity, ergosterol inhibition, and UV-visible spectra) of active extracts. The results were promising and showed that the metabolites produced by the actinomycete strains do not have a UVvisible spectrum characteristic of a polyenic structure. The Chaabe Cave possesses a diversity of microorganisms that could lead to new antibiotics necessary in the fight against drug-resistant pathogens and warrant further study.
\end{abstract}

Keywords: $\quad$ antimicrobial activities, cave microorganisms, Streptomyces, Penicillium, Chaabe Cave Received 21 August 2017; Revised 8 May 2018; Accepted 18 May 2018

Citation: Belyagoubi L., Belyagoubi-Benhammou N., Jurado V., Dupont J., Lacoste S., Djebbah F., Ounadjela F.Z., Benaissa S., Habi S., Abdelouahi D.E. and Saiz-Jimenez C., 2018. Antimicrobial activities of culturable microorganisms (actinomycetes and fungi) isolated from Chaabe Cave, Algeria. International Journal of Speleology, 47 (2), 189-199. Tampa, FL (USA) ISSN 0392-6672 https://doi.org/10.5038/1827-806X.47.2.2148

\section{INTRODUCTION}

The World Health Organization stated that there is a serious lack of new antibiotics to fight the increasing risk of antimicrobial resistance, which represents a global health emergency (Kmietowicz, 2017). Antibiotics and other bioactive compounds have been isolated from microorganisms in different environments, mainly marine (Dharmaraj, 2010; Romano et al., 2017) and terrestrial (Charousová et al., 2017; Devi et al., 2017), although novel compounds from plants have recently been described (Romero et al., 2017, 2018).

In the last decades the search for novel bioactive compounds has included the exploration of little investigated environments of which caves are an 
example. Karstic caves are widely distributed on all continents. Many caves have yet to be discovered or have barely been accessed, while other caves have received considerable attention due to tourist interest and have, therefore, been visited by a large number of people. This has contributed to their deterioration as can be seen with Lascaux Cave in France and Altamira Cave in Spain. (Bastian et al., 2010; SaizJimenez et al., 2011).

Almost two decades ago, Groth et al. (1999) suggested that caves were a promising environment for finding novel actinomycetes able to produce bioactive compounds. From that time on, a number of papers reported the isolation of cave actinobacteria with production of bioactive compounds (Nakaew et al., 2009; Hodges et al., 2012; Cheeptham et al., 2013; Ghosh et al., 2016; Maciejewska et al., 2016). The most promising was the discovery of cervimycin A-D, a polyketide complex produced by a strain of Streptomyces tendae, isolated from Grotta dei Cervi, in Italy. Cervimycins showed significant activity against multi-drug-resistant staphylococci and vancomicinresistant enterococci (Herold et al., 2005).

A number of caves should be considered oligotrophic in nature meaning that they have a very low organic carbon input. Given these circumstances, microorganisms compete for nutrients and their metabolic capabilities are enhanced over the bioactive substance production inhibiting the growth of other microorganisms (Cheeptham, 2013).

Algeria is a large country in Africa, with a remarkable abundance of flora and fauna. At present, there is little information on the microbial diversity of caves all over the world and, according to our knowledge, no publication has investigated the microbial diversity in cave ecosystems in either Algeria or Africa in general. In light of this, the main aim of the study was the identification of cultivable microorganisms (actinomycetes and fungi) with antimicrobial potential from Chaabe Cave (Tlemcen, Algeria). The isolates were identified by $16 \mathrm{~S}$ rRNA gene analyses for actinomycetes and ITS region or $\beta$ tubulin gene analyses for fungi and tested for their bioactive compounds.

\section{MATERIALS AND METHODS}

\section{Samples}

Samples were collected from Chaabe Cave in Tagema, near the city of Tlemcen (Algeria) (Western region: $34^{\circ} 53^{\prime} \mathrm{N}, 1^{\circ} 19^{\prime} \mathrm{W}, 1032 \mathrm{~m}$ altitude) (Fig. 1A; Carte du monde, 2017). The cavern access was characterized as difficult with a narrow entry and was not accessible to visitors. At present, there are no geological studies or physicochemical characteristics available about the cave. A total of four samples were collected aseptically and randomly from various sediments between February and March of 2016 (Fig. 1B). The samples (200-2,000 g) were taken from a depth of $0-20 \mathrm{~cm}$ below the surface with a large sterile spatula and placed in sterile polyethylene bags, closed tightly and stored at $4^{\circ} \mathrm{C}$ until used for further experiments.

\section{Measurement of $\mathbf{p H}$}

An aliquot of the sediment was air-dried at room temperature for 7 days, crushed and passed through a $2 \mathrm{~mm}$ mesh sieve. Twenty grams of a dried sample were suspended in $50 \mathrm{~mL}$ of distilled water and mixed to ensure uniformity. After a few minutes of standing, the supernatant was used to determine the $\mathrm{pH}$ with a digital pH meter (HANNA Inst. pH 209).

\section{Total aerobic mesophilic microorganism counts}

Ten grams of each sample were added to $90 \mathrm{~mL}$ of $0.9 \%(\mathrm{w} / \mathrm{v})$ solution of sodium chloride. After homogenization, this solution was diluted $\left(10^{-1}\right.$ to $\left.10^{-7}\right)$ and $1 \mathrm{~mL}$ of the resulting solution was inoculated on Plate Count Agar (PCA). After incubation at $25^{\circ} \mathrm{C}$, for 2 to 3 days, the colony forming units (CFU) were counted. Previous studies demonstrated that colonies from cave samples grow very slowly at cave temperature and that the diversity of the culturable genera was similar whether the bacteria were grown at cave temperature $\left(13^{\circ} \mathrm{C}\right)$ or at laboratory temperature $\left(28^{\circ} \mathrm{C}\right)$ (Groth et al., 2001; Laiz et al., 2003).

\section{Isolation of actinomycetes}

Under aseptic conditions, the sediment samples were air dried for 1 week prior isolation according to Jeffrey (2008) to decrease the population of Gram negative bacteria. The samples were then crushed in a sterile mortar. Isolation and enumeration of actinomycetes were performed by the dilution plate technique. Ten grams of sample was mixed with $90 \mathrm{~mL}$ of sterile water containing $\mathrm{NaCl} 9 \mathrm{~g} \cdot \mathrm{L}^{-1}$. The mixture was shaken vigorously at room temperature. Portions $(1 \mathrm{~mL})$ of the suspensions (diluted $10^{-1}$ ) were transferred to 9 $\mathrm{mL}$ of saline solution and subsequently diluted until $10^{-6}$ and/or $10^{-9}$ after homogenization by vortexing. The inocula, consisting of $100 \mu \mathrm{L}$ of these dilutions, were spread over the surface of a few isolation media: Chitin-B vitamin agar medium (Hayakawa \& Nonomura, 1987), Olson's medium (Olson, 1968), Bennett's medium (Boudemagh et al., 2005) and Tryptic soy agar medium (Romanenko et al., 2008). The four media were supplemented with $50 \mu \mathrm{g} \cdot \mathrm{mL}^{-1}$ cycloheximide (actidione) and $30 \mu \mathrm{g} \cdot \mathrm{mL}^{-1}$ nystatin to inhibit the development of antagonist fungi and other eukaryotic microorganisms (Williams and Davies 1965; Ouhdouch et al., 2001; Badji et al., 2005). Ten $\mu \mathrm{g} \cdot \mathrm{mL}^{-1}$ nalidixic acid were also added to plates in order to suppress Gram negative bacterial growth (Takizawa et al., 1993). All the inoculated plates were incubated in the dark at $28 \pm 2{ }^{\circ} \mathrm{C}$ for $2-4$ weeks and examined daily for colony patterns and growth. Actinomycete colonies with different morphologies were selected and streaked onto fresh Bennett or Tryptic soy agar slants and incubated at $28 \pm 2{ }^{\circ} \mathrm{C}$ for 1 week. Pure cultures were stored at $4^{\circ} \mathrm{C}$ or as suspensions in culture medium-glycerol at $-80^{\circ} \mathrm{C}$.

\section{Phenotypic identification of actinomycetes}

Actinomycete strains were identified according to traditional morphological criteria, including the phenotypical aspect of the colony and growth characteristics on Bennett and starch-casein media, 

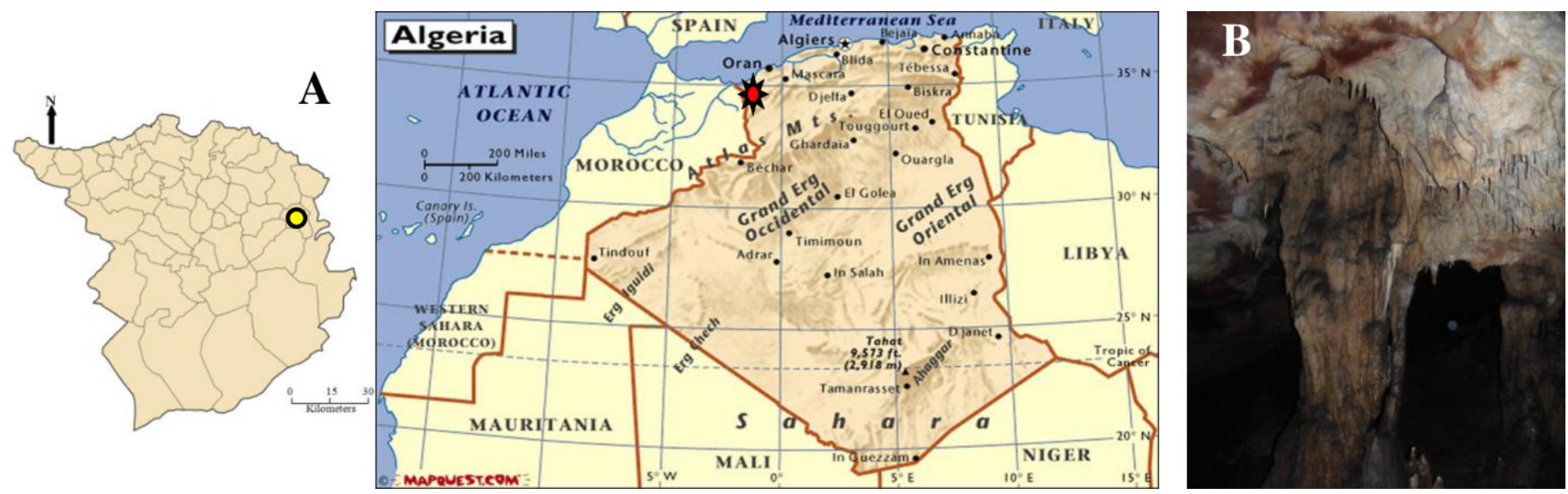

Fig. 1. A) Location of the Chaabe Caven ( City of Tlemcen; O- Cave in Tagema) and B) Sampling site.

morphology of aerial hyphae and spores. Microscopic morphologies were observed by light microscopy. The isolates were characterized using Gram's staining, physiological and biochemical studies which included assessment of the isolates' ability to utilize different carbon sources (glucose, lactose, saccharose, and citrate), formation of indole and $\mathrm{H}_{2} \mathrm{~S}$, catalase and urease activities, hydrolysis of starch, casein, gelatine, production of melanin, nitrate reductase activity and action on skimmed milk (coagulation and peptonisation) (Shirling \& Gottlieb, 1966; Marchal et al., 1991; Singleton, 1999).

\section{Sequencing and molecular identification of actinomycetes}

Bacterial DNA was extracted following the method described by Marmur (1961). The 16S rRNA gene was amplified by PCR using the conserved primers $27 \mathrm{~F}$ (5'-AGAGTTTGATCCTGGCTCAG) and 1522R (5'-AAGGAGGTGATCCAGCCGCA). PCR thermal conditions were as follows: $95^{\circ} \mathrm{C}$ for $60 \mathrm{~s} ; 35$ cycles of $95^{\circ} \mathrm{C}$ for $15 \mathrm{~s}, 55^{\circ} \mathrm{C}$ for $15 \mathrm{~s}, 72^{\circ} \mathrm{C}$ for $120 \mathrm{~s}$; and a final extension cycle at $72^{\circ} \mathrm{C}$ for $10 \mathrm{~min}$. Forward and reverse strands of the amplified DNA fragment were sequenced in an ABI 3700 sequencer (Applied Biosystems). Pairwise 16S rRNA gene sequence similarities for the most closely related strains were determined using the global alignment algorithm on the EzTaxon server (http://www.eztaxon.org) (Chun et al., 2007).

\section{Isolation of fungi}

Different culture media were employed to improve the isolation of fungi from the samples: Malt Extract Agar (MEA), Czapek Dextrose Agar with (CDAr) and without Rose Bengal (CDA), and Potato Dextrose Agar (PDA) with Rose Bengal or with 25\% lactic acid (Atlas, 2010).

Samples (10 g) were suspended in $90 \mathrm{~mL}$ of $0.9 \%$ sterile saline solution and mixed thoroughly by shaking. Subsequently serial 10 -fold dilutions were performed and $1 \mathrm{~mL}$ aliquots of $10^{-1}$ to $10^{-9}$ dilutions of each sample were plated onto the five media. All plates were incubated at $25^{\circ} \mathrm{C}$ for 1 week in the dark to reproduce the same natural conditions in the cave.

Fungal isolates were studied according to their phenotypic characteristics, such as color and texture of the surface colony, hyphal pigmentation, size and shape of conidia and conidiogenous cells, presence or absence of sclerotia, and growth rates. The number of colony forming units per g of dry weight (CFU/g dwt) was calculated for each sample. The isolated fungi were maintained as pure culture in PDA with 25\% lactic acid and kept at $4^{\circ} \mathrm{C}$ until further study.

\section{Sequencing and molecular identification of fungi}

Fungal DNA was extracted from fresh mycelium grown on MEA. Extractions were performed using the DNeasy Plant Mini Kit (Qiagen) following the manufacturer's instructions. ITS and the $\beta$ tubulin gene were amplified using primers sets ITS4/ITS5 (White et al., 1990) or Bt2A/Bt2B (Glass \& Donaldson, 1995), respectively.

PCR amplifications were performed using a BioRad DNA Engine Peltier Thermal cycler with 30 cycles of $30 \mathrm{~s}$ at $94^{\circ} \mathrm{C}, 30 \mathrm{~s}$ at $55^{\circ} \mathrm{C}$ (for both primer set), $40 \mathrm{~s}$ at $72^{\circ} \mathrm{C} ; 10 \mathrm{~min}$ at $72^{\circ} \mathrm{C}$, in a $25 \mu \mathrm{L}$ reaction mix, containing $12.5 \mu \mathrm{L}$ genomic DNA (dilution: $10^{-2}$ after extraction), $5 \mu \mathrm{L}$ PCR Direct Loading Buffer with $\mathrm{MgCl}_{2}$ (Q-Biogen), $0.5 \mu \mathrm{L}$ dNTPs (6.25 mM, dNTP Mix, Q-Biogen), $1 \mu \mathrm{L}$ of each $10 \mu \mathrm{M}$ primer (Eurogentec), $0.125 \mu \mathrm{L}$ Taq DNA Polymerase (Q-Biogen, 5 units/ $\mu \mathrm{L}$ ), and $4.875 \mu \mathrm{L}$ sterile water. PCR products were purified and sequenced by Genoscreen (Lille, France) in both directions to confirm the accuracy of each sequence. Sequences were assembled with CodonCode Aligner v. 3.7.1 (Codon Code Corporation), checked by visual inspection of the chromatograms and edited if necessary. Sequences were identified using the BLAST option at http://blast.st-va.ncbi.nlm.nih.gov/ Blast.cgi.

\section{In vitro screening of isolates for antimicrobial activity}

Antimicrobial activity of selected strains was estimated by the agar cylinders method, against four Gram-positive bacteria: Staphylococcus aureus (ATCC 6538), Micrococcus luteus (CIP 53.45/ATCC 9341), Listeria monocytogenes (ATCC 19111) and Bacillus subtilis (ATCC 6633), three Gram-negative bacteria: Pseudomonas aeruginosa (ATCC 27853), Escherichia coli (CIP 53.126 / ATCC 8739), and Klebsiella pneumoniae (IBMC Strasbourg), and the yeast Candida albicans (CIP 444). All of these microorganisms were kindly provided by the National Museum of Natural 
History (Paris, France) and the Laboratories of Natural Products and of Antibiotics (Tlemcen, Algeria).

\section{Agar cylinders method}

Inhibition zones were determined against selected pathogenic microorganisms using the disc diffusion method (Clinical and Laboratory Standards Institute, 2012), with necessary modifications. Bacterial suspensions were prepared in Mueller Hinton Broth (MHB) and fungal suspension in Sabouraud Dextrose Broth (SDB), and then incubated at $37^{\circ} \mathrm{C}$ for 24 $\mathrm{h}$ and at $30^{\circ} \mathrm{C}$ for $24-48 \mathrm{~h}$, respectively. The tested microorganism suspension was adjusted to a similar optical density to that of McFarland $0.5\left(10^{8} \mathrm{CFU} / \mathrm{ml}\right.$ for bacteria in MHB and $10^{6} \mathrm{CFU} / \mathrm{ml}$ in SDB for $C$. albicans). The isolated actinomycete and Penicillium strains were grown on Bennett's agar plates (Jones, 1949) for 14 days at $28^{\circ} \mathrm{C}$ and on Potato Dextrose Agar plates for 1 week at $25^{\circ} \mathrm{C}$, respectively. Then a calibrated cylinder $(6 \mathrm{~mm}$ in diameter $)$ was cut out and placed on Mueller Hinton agar (Sabouraud Dextrose agar for C. albicans) plates inoculated with the adjusted suspension of an exponentially growing culture of test microorganisms using a sterile cotton swab. To compare the antimicrobial activities, standard antibiotic disks were used as positive controls, ampicillin (10 $\mathrm{g} /$ disc; Biomaxima) and chloramphenicol (30 $\mu \mathrm{g} /$ disc; Sigma Aldrich) for bacteria, and nystatin (100 $\mathrm{\mu g} /$ disc; Sigma) and amphotericin B (100 $\mu \mathrm{g} /$ disc; Sigma) for yeast in order to control the sensitivity of the tested microorganism. Plates were first kept at $4{ }^{\circ} \mathrm{C}$ for $2-4 \mathrm{~h}$ to allow the diffusion of any antimicrobial metabolites. Inhibition diameters were determined after $24 \mathrm{~h}$ for bacterial strains and $48 \mathrm{~h}$ for C. albicans. Plates were examined for evidence of antimicrobial activities, represented by a zone of inhibition of microbial growth around the cylinders (Lemriss et al., 2003; Mellouli et al, 2003; Kitouni et al., 2005).

\section{Screening for actinomycete strains producing nonpolyenic antifungal metabolites}

To select active actinomycete strains producing only nonpolyenic antifungal agents, the ergosterol inhibition and the production of active metabolites were investigated. Ergosterol inhibition was tested by the diffusion method (agar cylinders method) on Sabouraud's agar medium with or without $50 \mathrm{mg} \cdot \mathrm{mL}^{-1}$ ergosterol, in the presence of C. albicans (Ouhdouch et al., 2001).

For the production and extraction of active metabolites, isolates showing antifungal activity were cultured in a $250 \mathrm{~mL}$ flask containing $25 \mathrm{~mL}$ of liquid Bennett's medium and incubated at $37^{\circ} \mathrm{C}$ for $24 \mathrm{~h}$. The culture was transferred into a $500 \mathrm{~mL}$ flask containing $225 \mathrm{~mL}$ of liquid Bennett's medium. After 3 days of incubation at $37^{\circ} \mathrm{C}$, either the whole culture was extracted twice with ethyl acetate $(1: 1, \mathrm{v} / \mathrm{v})$, or the pellet and the supernatant (obtained after centrifugation at 4,500 $\mathrm{rpm}$ for $15 \mathrm{~min}$ ) were extracted with methanol $(1: 5$, $\mathrm{v} / \mathrm{v})$ and twice with hexane $(1: 1, \mathrm{v} / \mathrm{v})$, respectively. The antifungal activity of the three extracts for each active strain was determined by the disc diffusion method (Lemriss et al., 2003). The UV-visible spectra of the active extracts were recorded in the 200-500 $\mathrm{nm}$ range with a spectrophotometer (JENWAY2750 UV.vis) (Hacène et al., 1994; Ouhdouch et al., 2001).

\section{RESULTS AND DISCUSSION}

\section{Samples and isolation of actinomycetes}

Actinomycete colonies were counted on different media plates after $14-28$ days of incubation at $28^{\circ} \mathrm{C}$. Actinomycetes were recognized by their morphological characteristics: tough leathery colony, branched vegetative mycelia, and, when present, aerial mycelia and spore formation. All bacterial strains were Grampositive. Most of the colonies that grew on plates belonged to the genus Streptomyces since the colonies were slow growing, aerobic, glabrous or chalky, heaped, folded and with aerial and substrate mycelia of different colors (gray, white, red, yellow, green, beige, purple, brown, violet and orange) (Buchanan $\&$ Gibbons, 1974). Four different media were used for the isolation of actinomycetes from cave: Chitin-B vitamin agar, Olson's medium, Bennett's agar, and Tryptic soy agar. In addition, the media MEA and CDA, used for the isolation of cave fungi, also allowed for the isolation of the actinomycetes.

Forty seven actinomycete strains were isolated using different culture media from the four cave samples (Table 1). The number of isolates recovered from each sample varied widely and ranged from 2 to 14. Considering the used media, Olson's medium yielded the greatest percentage of actinomycetes (29.79\%), followed by Bennett's agar (21.28\%). However, the macroscopic morphological diversity noticed on Olson's medium was substantially less than in the others. The higher morphological diversity was observed on both media TSA and Bennett's Agar.

\section{Identification of actinomycetes}

The isolates were easily identified as actinomycetes by their morphology and strong adherence to the agar medium. Some isolates produced diffusible pigments on several agar media and melanin on peptone-yeast extract agar (ISP6) (Shirling \& Göttlieb, 1966). The degradation of the substrates casein, starch and gelatin was variable according to each isolate. An isolate (strain A45) was affiliated to the genus Streptomyces using taxonomic features. For the identification of the remaining actinomycetes a molecular approach was used, resulting in the affiliation of all strains to the genus Streptomyces. In Table 2 the representative strains are shown. BLAST search revealed that the closest hits to each cave isolate were Streptomyces species displaying a similarity of between 98.76

Table 1. Number and percentage of actinomycetes isolated by culture medium.

\begin{tabular}{|c|c|c|c|c|c|c|}
\hline Medium & TSA & Bennett & Olson & Chitin & MEA & CDA \\
\hline Number of isolated actinomycetes & 6 & 10 & 14 & 7 & 8 & 2 \\
\hline Total \% & 12.76 & 21.28 & 29.79 & 14.89 & 17.02 & 4.25 \\
\hline
\end{tabular}


Table 2. Phylogenetic affiliations of the active isolates.

\begin{tabular}{|l|c|c|}
\hline \multicolumn{1}{|c|}{ Strains } & EZtaxon affiliation* & Similarity (\%) \\
\hline A1 & S. ambofaciens & 99.58 \\
\hline A10 & S. rimosus & 99.02 \\
\hline A13 & S. albospinus & 99.48 \\
\hline A15 & S. staurosporininus & 98.81 \\
\hline A22 & S. aureoverticillatus & 99.11 \\
\hline A27, A36 S. anulatus (1) & 99.93 \\
\hline A2, A3, A5, A7, A8, A11, A12, A16, and A47 & S. celluloflavus (2) & 98.76 \\
\hline
\end{tabular}

*Taxonomic groups that include species not distinguishable by $16 \mathrm{~S}$ rRNA sequence:

(1) S. griseus subsp. griseus, S. fulvissimus, S. anulatus, S. cinereorectus, S. microflavus, S. cyaneofuscatus,

S. griseoplanus, S. setonii, S. fulvorobeus, S. halstedii, S. griseolus, S. puniceus, S. griseorubiginosus, S. badius,

S. parvus, S. sindenensis, S. pluricolorescens, S. rubiginosohelvolus. (2) S. celluloflavus, S. kasugaensis.

and $99.93 \%$. A few of these strains showed some morphological differences and were included in the taxonomic group of $S$. griseus and $S$. fradiae.

On the basis of the 16S rRNA gene sequences similarity, two strains (A36 and A27) were most closely related to several species belonging to the taxonomic group $S$. griseus which includes $S$. griseus subsp. griseus, S. fulvissimus, S. anulatus, S. cinereorectus, S. microflavus, S. cyaneofuscatus, $S$. griseoplanus, S. setonii, S. fulvorobeus, S. halstedii, S. griseolus, S. puniceus, S. griseorubiginosus, S. badius, S. parvus, S. sindenensis, S. pluricolorescens and $S$. rubiginosohelvolus. Also strains A12, A2, A3, A5, A7, $\mathrm{A} 8, \mathrm{~A} 11, \mathrm{~A} 16$ and $\mathrm{A} 47$ were affiliated to the taxonomic group S. fradiae, which includes S. celluloflavus and S. kasugaensis among others.

Previous studies reported that the utilization of $16 \mathrm{~S}$ rRNA gene sequences is not sufficient to discriminate between closely related species of the genus Streptomyces (Guo et al., 2008; Rong et al., 2009). To this end, a detailed study for species identification requires multilocus sequence analysis (MLSA): atpD (ATP synthase $\beta$-subunit), gyrB (DNA gyrase $\beta$-subunit), recA (recombinase A), rpoB (RNA polymerase $\beta$-subunit) and $\operatorname{trp} B$ (tryptophan synthase $\beta$-subunit) and DNADNA hybridization (Dominguez-Moñino et al., 2017), an approach that is out of our scope.

Cultivable members of the genus Streptomyces have been previously reported from different caves, however isolates belonging to other genera, have been found through both culture-dependent and independent approaches (Groth et al., 1999, 2001; Nakaew et al., 2009; Stomeo et al., 2009; Niyomvong et al., 2012). Taking into consideration the numerous studies on cave microbial diversity, it is worth noting that each cave seems to be unique and diverse in its microbial compositions, however, there is a trend of finding dominating actinobacterial communities in many caves (Cheeptham et al., 2013). The reason for the large recovery of Streptomyces in caves can lie in their spore dispersal, the ability to use a large variety of nutrient sources in synthetic rich media and their more rapid growth in comparison to other genera, recognized as rare Actinobacteria, which are isolated much less frequently (Subramani \& Aalbersberg, 2013; Maciejewska et al., 2016).

The importance of cave actinomycetes as producers of bioactive substances was stressed in the past (Groth et al., 1999). Indeed, members of the genus Streptomyces are notable for their ability to produce a wide variety of pharmaceutically useful compounds as secondary metabolites (Huang et al., 2005). Many of these secondary metabolites are potent antibiotics, which has made streptomycetes the primary antibioticproducing organisms exploited by the pharmaceutical industry (Jensen et al., 2007; Ramesh et al., 2009).

\section{Antimicrobial activity of actinomycetes}

The antimicrobial potential of cave actinobacteria, and especially Streptomyces, has received the attention of many scientists and it is a topic of great interest (Herold et al., 2005; Hodges et al., 2012; Cheeptham, 2013; Rule \& Cheeptham, 2013; Nimaichand et al., 2015).

The results of the initial screening of 47 strains for antibacterial and antifungal activity are summarized in Table 3. Overall, the tested actinomycetes showed antimicrobial activity against at least one of the tested pathogenic strains by agar cylinders method. The lowest activities were exhibited against Gramnegative bacteria. Indeed, $61.70 \%$ of the tested isolates were active against $S$. aureus, $57.45 \%$ against M. luteus, $36.17 \%$ against B. subtilis, $29.79 \%$ against L. monocytogenes, while $21.28 \%$ were active against $E$. coli and only $8.51 \%$ against $K$. pneumoniae. However, we observed an absence of antimicrobial activity against $P$. aeruginosa.

Maciejewska et al. (2016) studied the cultivable Streptomyces isolated from cave moonmilk deposits which showed a much stronger antibacterial activity against Gram-positive bacteria ( $94 \%$ of the phylotypes) than against Gram-negative bacteria $(71 \%$ of the phylotypes). In addition, the data showed that the antifungal activity was exhibited in $14.89 \%$ of all isolates.

\section{Screening for antifungal polyenic and nonpolyenic metabolites}

After primary screening for antimicrobial activity of the 47 isolates by agar cylinders method against pathogenic microbes, five strains of Streptomyces sp. (A5, A11, A16, A22, and A45) were selected for further analysis, since they showed significant antifungal activity against the yeast $C$. albicans. In addition, these strains exhibited good activity against tested Gram-positive bacteria compared to Gram-negative bacteria (Table 4). The inhibition zone diameter for $C$. albicans was more than $8.5 \mathrm{~mm}$.

These five isolates appeared promising because of their activity against $S$. aureus, $M$. luteus, B. subtilis, 

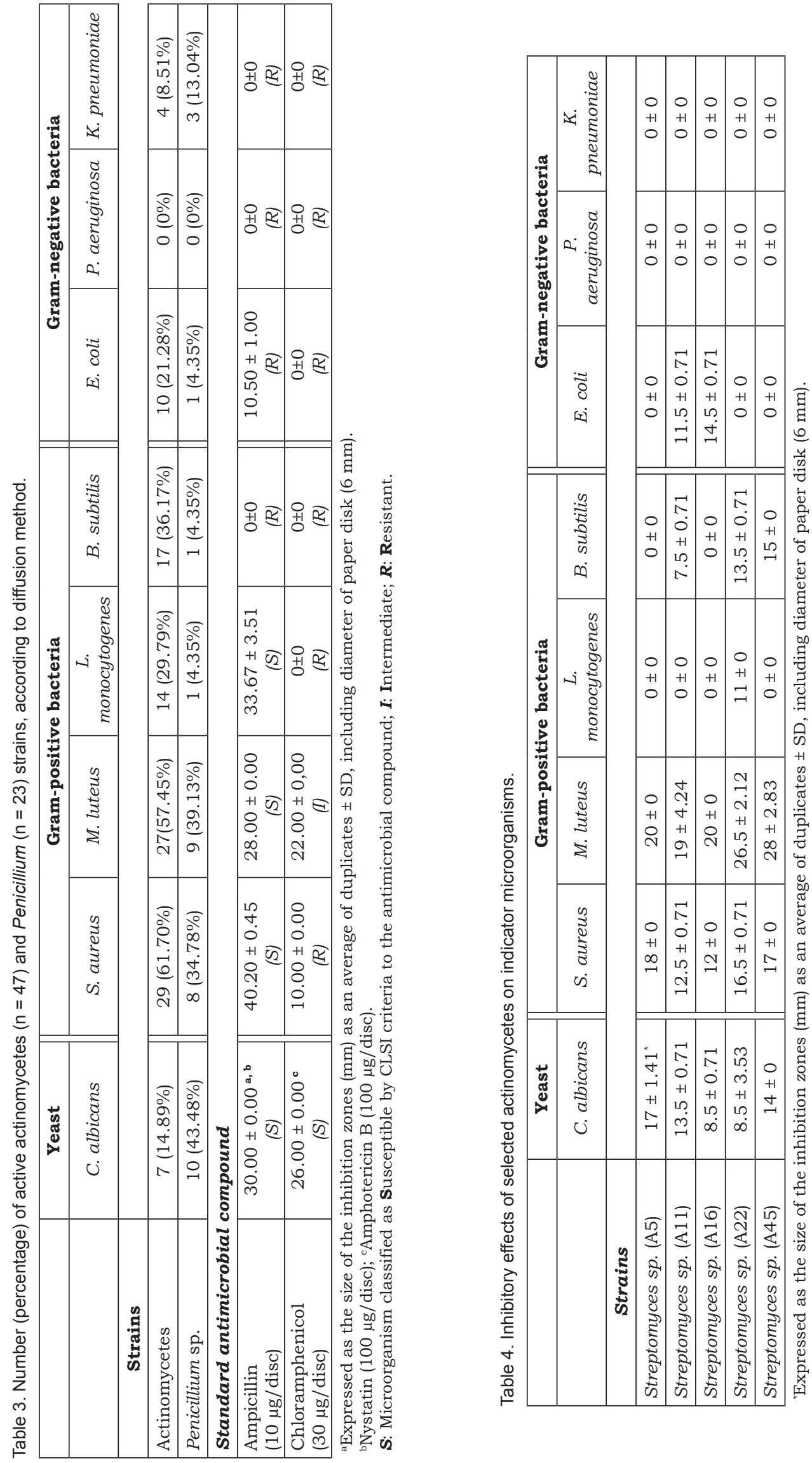
and $E$. coli (cell membrane without sterols) but they showed a marked inhibition of antifungal activity by exogen ergosterol, which is considered to be a target of polyenic antifungal compounds (Bastide et al., 1986). A reduction of the inhibition zone in the presence of ergosterol is an indication of the presence of polyene metabolites. For nonpolyenic metabolites, no interaction occurs and the diameter of the inhibition zones remains constant (Hamilton-Miller, 1973). This allowed us to easily detect the absence or production of polyenic metabolites. The five Streptomyces strains showed an absence of inhibition zones (Table 5).

Several authors have used UV-visible spectroscopic analyses of the active extracts to distinguish between polyenic and nonpolyenic substances (Hacène et al., 1994; Ouhdouch et al., 2001; Lemriss et al., 2003). The spectra of polyenes are characterized by a series of bands between 260 and 405 nm (Hamilton-Miller, 1973). However the metabolites produced by the five strains of Streptomyces did not show an UV-visible spectrum characteristic of a polyenic structure.

To summarize, the five strains of Streptomyces sp. showed activity against C. albicans and bacteria, and the inhibition zones were markedly reduced after the addition of exogenous ergosterol. However, the extracts did not reveal polyene-type UV-visible spectra. These contradictory results have been explained by a coproduction of polyene and non-polyene products by the same strain (Lemriss et al., 2003).

Table 5. Three step screening method for nonpolyenic antifungal agents.

\begin{tabular}{|l|c|c||c|c||c|}
\hline & \multicolumn{2}{|c|}{ Antibacterial activity } & \multicolumn{2}{|c|}{ Ergosterol effect ${ }^{\text {a }}$} & UV-visible spectroscopic analysis \\
\cline { 3 - 4 } & $\begin{array}{c}\text { Gram-positive } \\
\text { bacteria }\end{array}$ & $\begin{array}{c}\text { Gram-negative } \\
\text { bacteria }\end{array}$ & Without & With & Polyene absorption (nm) \\
\hline S. celluloflavus (A5) & S, M & - & $17 \pm 1$ & $0 \pm 0$ & No Detected \\
\hline S. celluloflavus (A11) & S, M, B & E & $13.5 \pm 0.5$ & $0 \pm 0$ & No Detected \\
\hline S. celluloflavus (A16) & S, M & E & $8.5 \pm 0.5$ & $0 \pm 0$ & No Detected \\
\hline S. aureoverticillatus (A22) & S, M, B & - & $10.5 \pm 0.5$ & $0 \pm 0$ & No Detected \\
\hline Streptomyces sp. (A45) & S, M, B & - & $14 \pm 0$ & $0 \pm 0$ & No Detected \\
\hline
\end{tabular}

aActivity measured by diameter of inhibition zones (in $\mathrm{mm}$ ).

S: Staphylococcus aureus ATCC 6538; M: Micrococcus luteus ATCC 9341; B: Bacillus subtilis ATCC 6633; E: Escherichia coli ATCC 8739.

\section{Enumeration of viable counts and fungi}

The enumeration of the aerobic mesophilic microorganisms was done in order to develop an idea about the cave microbiology and on the total microbial count of cave sediments where the strains were isolated.

Table 6 summarizes the microbial counts obtained and $\mathrm{pH}$ values from various samples in Chaabe Cave. The $\mathrm{pH}$ of the four samples ranged from 7.45 to 8.48 .

In all samples, the count of total aerobic mesophilic microorganisms was significantly greater than the number of isolated fungi. CFU counts on PCA were the highest in sample $2\left(6.8 \times 10^{5} \mathrm{CFU} \cdot \mathrm{g}^{-1},\right)$ whereas samples 1,3 , and 4 with values of $2 \times 10^{5} \mathrm{CFU} \cdot \mathrm{g}^{-1}$, $2.78 \times 10^{4} \mathrm{CFU} \cdot \mathrm{g}^{-1}$, and $2.18 \times 10^{5} \mathrm{CFU} \cdot \mathrm{g}^{-1}$, respectively were about three times lower. Fungal counts were higher in samples 1 and 2, when compared with the last two samples. Growth was better in the media CDAr and MEA as compared to PDA. Altogether 38 isolates of fungi were obtained from the four cave samples using different solid media. Most of the isolates were obtained from samples 1 and 2 , those located less deep in the cave, which probably denotes a higher input from outside fungi.

\section{Mycobiota diversity}

In total, 38 filamentous fungi isolates were picked from plates and identified. Species of Penicillium,
Cladosporium, Aspergillus and Alternaria account for a high proportion of the strains examined, but representatives of other genera are also included.

Cultural analysis, macroscopic and microscopic characteristics of mycoflora on cave samples revealed the presence of eight genera indicating a diverse fungal community in our cave. The genera were (in the order of relative abundance) Penicillium spp. (60.53\%; $\mathrm{n}=23$ ) as the most abundant, followed by Cladosporium spp. (10.53\%; $\mathrm{n}=4)$, Alternaria sp. and Aspergillus sp. (7.89\%; $\mathrm{n}=3$ ), Beauveria sp. (5.26\%; $\mathrm{n}=2$ ), Rhizopus sp., Rhizomucor sp., and Readeriella sp. $(2.63 \% ; n=1)$ (Fig. 2). The identification at the species level was determined by sequence analysis of ITS rRNA or of partial $\beta$ tubulin gene. Taking their similarities to sequences in GenBank, we identified 5 species: Readeriella eucalypti, Cladosporium pseudocladosporioides, Aspergillus wentii, Penicillium brevicompactum, Amphicorda felina (= Isaria felina = Beauveria felina).

Man et al. (2015) studying the phylogenetic diversity of culturable fungi in the Heshang Cave (China) reported that the genus Penicillium was the most abundant and accounted for 40, 54, and 52\% of cultivable fungi in the sediments, weathered rocks and bat guano, respectively. Some other abundant fungal genera were Trichoderma, Paecilomyces, and Aspergillus, but in weathered rocks the presence

Table 6. The $\mathrm{pH}$, total viable counts and fungi counts $\left(\mathrm{cfu} . \mathrm{g}^{-1}\right)$ of different samples from Chaabe Cave.

\begin{tabular}{|l|c|c|c|c|c|c|c|}
\hline & pH & PCA & CDA & CDAr. & PDAr. & PDAac. & MEA \\
\hline Sample 1 & $8.48 \pm 0.04^{\mathrm{a}}$ & $2.10^{5 \mathrm{~b}}$ & $4.10^{3}$ & $5.10^{3}$ & $5.10^{3}$ & $3.10^{3}$ & $10^{4}$ \\
\hline Sample 2 & $8.35 \pm 0.39$ & $6.8 .10^{5}$ & ND & $5.2 .10^{3}$ & $1.1 .10^{3}$ & $1.48 .10^{3}$ & $2.1 .10^{3}$ \\
\hline Sample 3 & $7.45 \pm 0.05$ & $2.78 .10^{4}$ & $9.10^{1}$ & $2.95 .10^{2}$ & $4.5 .10^{1}$ & $1.5 .10^{1}$ & $6.10^{1}$ \\
\hline Sample 4 & $7.54 \pm 0.05$ & $2.18 .10^{3}$ & ND & $10^{1}$ & $10^{1}$ & $3.10^{1}$ & ND \\
\hline
\end{tabular}

${ }_{\mathrm{a}, \mathrm{b}} \mathrm{The} \mathrm{pH}$ and the cfu/g correspond to an average number; ND: not determined. 
of Cladosporium and Beauveria felina were also significant. We also found the entomopathogenic fungus Amphicorda felina (= Beauveria feline) in cave floor surfaces collected by swabbing.

To the best of our knowledge, the present work is the first report on the isolation of the genus Readeriella from cave, a fungal genus associated to Eucaliptus leaves (Sánchez Márquez et al., 2011). For the other genera found in Chaabe Cave, Vanderwolf et al. (2013) stated that they are considered to be the most frequently reported compared with other studies on cave mycology and that fungi are not distributed evenly throughout caves. The distribution of cave mycobiota is influenced by the susceptibility of the rock material to be colonized, their mineral composition, porosity, etc. and by environmental conditions (water availability, temperature, $\mathrm{pH}$, and nutrient sources) (Gorbushina, 2007). Dickson and Kirk (1976) noted that more fungi and bacteria were found on the cave sediments than on the walls or ceiling, likely because organic carbon accumulates on the cave floor. In addition, bacteria are more uniformly distributed than fungi, which are often associated with invertebrates and organic matter (Jurado et al., 2008).

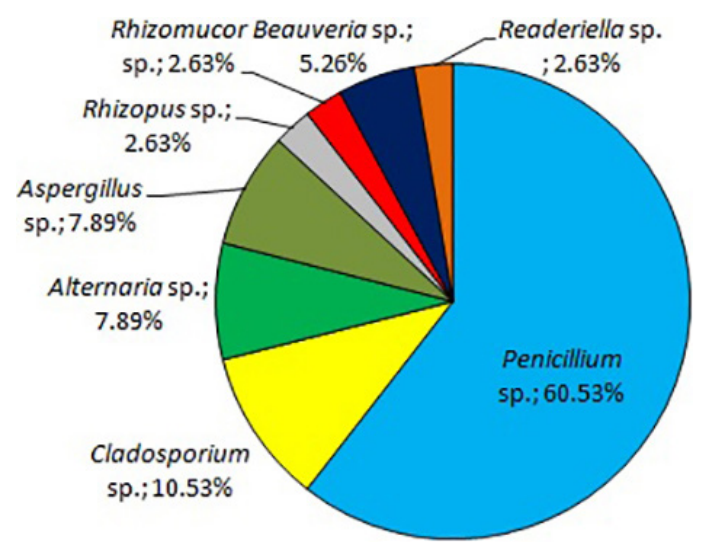

Fig. 2. Composition of fungal communities in the Chaabe Cave.

\section{Antimicrobial activity of Penicillium spp.}

A large number of fungal extracts and/or extracellular products have been found to have antimicrobial activity, mainly from species of the ubiquitous genus Penicillium (Rancic et al., 2006; Petit et al., 2009). A total of 23 strains of Penicillium were selected for screening of antimicrobial activity against pathogenic microorganisms.

The results of the initial screening of 23 strains for antibacterial and antifungal activity are summarized in Table 3. The Penicillium spp. tested showed antimicrobial activity against at least one of the tested microorganisms by agar cylinders method (except for $P$. aeruginosa which is the most resistant species) indicating that these fungi produce some type of antimicrobial substance(s) responsible for inhibiting the tested microorganisms. The active strains showed strong inhibitory activity opposed to the pathogenic microorganisms and the diameters of the inhibition zones vary between 7.5 and $26 \mathrm{~mm}$. The results showed the best activity against $C$. albicans with a percentage inhibition of $43.38 \%(10 / 23)$.

Several surveys of the antibacterial substance production by fungi have been published recently, from which it appears that many of the Ascomycetes, Basidiomycetes and Fungi Imperfecti show marked antibacterial activity but few, if any, of the Phycomycetes. The present account deals with a number of Fungi Imperfecti examined mostly for antifungal activity; a preliminary examination for antibacterial activity has also been made in most cases.

\section{CONCLUSION}

This is the first report on microbial communities in a natural pristine cave ecosystem in Algeria to our knowledge, and sheds light on microbial assemblages that can be a remarkable source of antimicrobial molecules. This study was aimed at investigating the antagonistic activity of actinomycetes and fungi from Chaabe Cave, Algeria, against pathogenic microorganisms. The microbial assemblages associated with this Algerian cave were investigated by culture-dependent method together with the analysis of $16 \mathrm{~S}$ rRNA gene sequences for actinomycetes and the fungal ITS or $\beta$ tubulin gene sequences. A large number of isolated microorganisms exhibited activity against pathogenic bacteria and/or fungi according to their origin. The desired outcome of this publication is to provide preliminary data that indicate the cave is a useful potential source for the isolation of microorganisms producing biologically active products. A few strains of Streptomyces and Penicillium produced antibiotics and likely an array of other secondary metabolites, which merit a more detailed investigation.

\section{ACKNOWLEDGEMENTS}

The authors would like to thank Dr. Séverine ZIRAH and Prof. Sylvie REBUFFAT from the National Museum of Natural History, Laboratory of Communication molecules and adaptation of microorganisms, UMR7245 CNRS (Paris, France), for their cooperation.

\section{REFERENCES}

Atlas R.M., 2010 - Handbook of microbiological media (4 $^{\text {th }}$ Ed.), vol. 1, CRC Press, Boca Raton. https://doi.org/10.1201/EBK1439804063

Badji B., Riba A., Mathieu F., Lebrihi A. \& Sabaou N., 2005 - Antifungal activity of a Saharan Actinomadura strain against various pathogenic and toxinogenic fungi. Journal of Medical Mycology, 15: 211-219.

https://doi.org/10.1016/j.mycmed.2005.07.001

Bastian F., Jurado V., Novakova A., Alabouvette C. \& Saiz-Jimenez C., 2010 - The microbiology of the Lascaux Cave. Microbiology, 156: 644-652. https://doi.org/10.1099/mic.0.036160-0

Bastide A., de Méo M., Andriantsoa M., Laget M. \& Duménil G., 1986 - Isolement et sélection de souches d'actinomycètes productrices de substances antifongiques de structure non-polyénique. MIRCEN Journal of Applied Microbiology and Biotechnology, 2: 453-466. https://doi.org/10.1007/BF00933368

Boudemagh A., Kitouni M., Boughachiche F., Hamdiken H., Oulmi L., Reghioua S., Zerizer H., Couble A., Mouniee D., Boulahrouf A. \& Boiron P., 2005 - Isolation 
and molecular identification of actinomycete microflora, of some Saharian soils of South East Algeria (Biskra, ELOued and Ourgla) study of antifungal activity of isolated strains. Journal of Medical Mycology, 15: 39-44.

https://doi.org/10.1016/j.mycmed.2004.12.004

Buchanan R.E. \& Gibbons N.E., 1974 - Bergey's manual of determinative bacteriology ( $8^{\text {th }}$ Ed.), Baltimore, Williams and Wilkins, p. 747-829.

Carte du Monde - http://www.carte-du-monde.net/ pays-12-carte-relief-algerie.html [accessed: August 20, 2017]

Charousová I., Steinmetz H., Medo J., Javoreková S. \& Wink J., 2017 - Soil myxobacteria as a potential source of polyketide-peptide substances. Folia Microbiologica, 62 (4): 305-315.

https://doi.org/10.1007/s12223-017-0502-2

Cheeptham N., 2013. Cave microbiomes: A novel resource for drug discovery, Springer Briefs in Microbiology, Springer, New York, 130 p.

Cheeptham N., Sadoway T., Rule D., Watson K., Moote P., Soliman L., Azad N., Donkor K.K. \& Horne D., 2013 - Cure from the cave: volcanic cave actinomycetes and their potential in drug discovery. International Journal of Speleology, 42 (1): 35-47.

https://doi.org/10.5038/1827-806X.42.1.5

Chun J., Lee J.H., Jung Y., Kim M., Kim S., Kim B.K., Lim Y.W., 2007 - EzTaxon: a web-based tool for the identification of prokaryotes based on 16S ribosomal RNA gene sequences. International Journal of Systematic and Evolutionary Microbiology, 57: 2259-2261. https://doi.org/10.1099/ijs.0.64915-0

Clinical and Laboratory Standards Institute, 2012 - Performance standards for antimicrobial disk susceptibility tests, approved standard M02-A11 $\left(11^{\text {th }} E d\right.$.). Clinical and Laboratory Standards Institute, Wayne, PA, $58 \mathrm{p}$.

Dharmaraj D., 2010 - Marine Streptomyces as a novel source of bioactive substances. World Journal of Microbiology and Biotechnology, 26: 2123-2139. https://doi.org/10.1007/s11274-010-0415-6

Devi S.I., Lotjem H., Devi E.J., Potshangbam M., Ngashangva N., Bora J., Sahoo D. \& Sharma C., 2017 - Bio-mining the forest ecosystem of North East India for identification of antimicrobial metabolites from fungi through submerged fermentation. Bioresource Technology, 241: 1168-1172.

https://doi.org/10.1016/j.biortech.2017.05.130

Dickson G.W. \& Kirk P.W., 1976 - Distribution of heterotrophic microorganisms in relation to detritivores in Virginia caves (with supplemental bibliography on cave mycology and microbiology). In: Parker B.C. \& Roane M.K. (Eds.), The distribution history of the biota of the Southern Appalachians. Part IV. Algae and Fungi. University Press of Virginia, Charlottesville, p. 205226.

Dominguez-Moñino I., Diaz-Herraiz M., Jurado V., Laiz L., Miller A.Z., Santos J.L., Alonso E. \& Saiz-Jimenez C., 2017 - Nature and origin of the violet stains on the walls of a Roman tomb. Science of the Total Environment, 598: 889-899.

https://doi.org/10.1016/j.scitotenv.2017.04.017

Ghosh S., Kuisiene N. \& Cheeptham N., 2016 - The cave microbiome as a source for drug discovery: Reality or pipe dream? Biochemical Pharmacology, 134: 18-34. https://doi.org/10.1016/j.bcp.2016.11.018

Glass N.L. \& Donaldson G.C., 1995 - Development of primer sets designed for use with the PCR to amplify conserved genes from filamentous ascomycetes. Applied and Environmental Microbiology, 61: 1323-1330.

http://aem.asm.org/content/61/4/1323.short
Gorbushina A., 2007 - Life on the rocks. Environmental Microbiology, 9: 1613-1615

https://doi.org/10.1111/j.1462-2920.2007.01301.x

Groth I., Vetermann R., Schuetze B., Schumann P. \& Saiz-Jimenez C., 1999 - Actinomycetes in kartic caves of Northern Spain (Altamira and Tito Bustillo). Journal of Microbiological Methods, 36: 115-122.

https://doi.org/10.1016/S0167-7012(99)00016-0

Groth I., Schumann P., Laiz L., Sanchez-Moral S., Cañaveras J.C. \& Saiz-Jimenez C., 2001 Geomicrobiological study of the Grotta dei Cervi, Porto Badisco, Italy. Geomicrobiology Journal, 18: 241-258. https://doi.org/10.1080/01490450152467778

Guo Y., Zheng W., Rong X. \& Huang Y., 2008 - A multilocus phylogeny of the Streptomyces griseus $16 \mathrm{~S}$ rRNA gen clade: use of multilocus sequence analysis for streptomycete systematics. International Journal of Systematic and Evolutionary Microbiology, 58: 149-159. https://doi.org/10.1099/ijs.0.65224-0

Hacène H., Sabaou N., Bounaga N. \& Lefevre G., 1994 - Screening for non-polyenic antifungal antibiotics produced by rare actinomycetales. Microbios, 79: 81-85.

Hamilton-Miller J.M.T., 1973 - Chemistry and biology of the polyene macrolide antibiotics. Bacteriological Reviews, 37: 166-196.

Hayakawa M. \&, Nonomura H., 1987 - Humic acidvitamins agar, a new medium for the selective isolation of soil actinomycetes. Journal of Fermentation Technology, 65: 501-509. https://doi.org/10.1016/0385-6380(87)90108-7

Herold K., Gollmick F.A., Groth I., Roth M., Menzel K.D., Möllmann U., Gräfe U. \& Hertweck C., 2005 Cervimycin A-D: a polyketide glycoside complex from a cave bacterium can defeat vancomycin resistance. Chemistry - A European Journal, 11: 5523-5530. https://doi.org/10.1002/chem.200500320

Hodges T.W., Slattery M. \& Olson J.B., 2012 - Unique actinomycetes from marine caves and coral reef sediments provide novel PKS and NRPS biosynthetic gene clusters. Marine Biotechnology, 14: 270-280.

https://doi.org/10.1007/s10126-011-9410-7

Huang J., Shi J., Molle V., Sohlberg B., Weaver D., Bibb M.J., Karoonuthaisiri N., Lih C.J., Kao C.M., Buttner M.J. \& Cohen S.N., 2005 - Cross-regulation among disparate antibiotic biosynthetic pathways of Streptomyces coelicolor. Molecular Microbiology, 58: 1276-1287. https://doi.org/10.1111/j.1365-2958.2005.04879.x

Jeffrey L.S.H., 2008 - Isolation, characterization and identification of actinomycetes from agriculture soils at Semongok, Sarawak. African Journal of Biotechnology, 7: 3697-3702.

https://doi.org/10.5897/AJB08.473

Jensen P.R., Williams P.G., Oh D.C., Zeigler L. \& Fenical W., 2007 - Species-specific secondary metabolite production in marine actinomycetes of the genus Salinispora. Applied and Environmental Microbiology, 73: 1146-1152. https://doi.org/10.1128/AEM.01891-06

Jones K.L., 1949 - Fresh isolates of actinomycetes in which the presence of sporogenous aerial mycelia is a fluctuating characteristic. Journal of Bacteriology, 57: 141-145.

Jurado V., Sanchez-Moral S. \& Saiz-Jimenez C., 2008 Entomogenous fungi and the conservation of the cultural heritage: A review. International Biodeterioration \& Biodegradation, 62: 325-330.

https://doi.org/10.1016/j.ibiod.2008.05.002 
Kitouni M., Boudemagh A., Oulmi L., Reghioua S., Boughachiche F., Zerizer H., Hamdiken H., Couble A., Mouniee D., Boulahrouf A. \& Boiron P., 2005 - Isolation of actinomycetes producing bioactive substances from water, soil and tree bark samples of the north-east of Algeria. Journal of Medical Mycology, 15: 45-51. https://doi.org/10.1016/j.mycmed.2004.12.005

Kmietowicz Z., 2017 - Few novel antibiotics in the pipeline, WHO warns. British Medical Journal, 358: j4339. https://doi.org/10.1136/bmj.j4339

Laiz L., Gonzalez-Delvalle M., Hermosin B., OrtizMartinez A., and Saiz-Jimenez C., 2003 - Isolation of cave bacteria and substrate utilization at different temperatures. Geomicrobiology Journal, 20: 479-489. https://doi.org/10.1080/713851125

Lemriss S., Laurent F., Couble A., Casoli E., Lancelin J.M., Saintpierre-Bonaccio D., Rifai S., Fassouane A. \& Boiron P., 2003 - Screening of nonpolyenic antifungal metabolites produced by clinical isolates of actinomycetes. Canadian Journal of Microbiology, 49: 669-674. https://doi.org/10.1139/w03-088

Maciejewska M., Adam D., Martinet L., Naômé A., Całusinska M., Delfosse P., Carnol M., Barton H.A., Hayette M.P., Smargiasso N., De Pauw E., Hanikenne M., Baurain D. \& Rigali S., 2016 - A phenotypic and genotypic analysis of the antimicrobial potential of cultivable Streptomyces isolated from cave moonmilk deposits. Frontiers in Microbiology, 7: 1455. https://doi.org/10.3389/fmicb.2016.01455

Man B., Wang H., Xiang X., Wang R., Yun Y. \& Gong L., 2015 - Phylogenetic diversity of culturable fungi in the Heshang Cave, central China. Frontiers in Microbiology, 6: 1158. https://doi.org/10.3389/fmicb.2015.01158

Marchal N., Bourdon J.L. \& Richard Cl., 1991 - Les milieux de culture pour l'isolement et l'identification biochimique des bactéries. Doin, Paris, 509 p.

Marmur J., 1961 - A procedure for the isolation of deoxyribonucleic acid from microorganisms. Journal of Molecular Biology, 3: 208-218.

https://doi.org/10.1016/ S0022-2836(61)80047-8

Mellouli L., Ben Ameur-Mehdi R., Sioud S., Salem M. \& Bejar S., 2003 - Isolation, purification and partial characterization of antibacterial activities produced by a newly isolated Streptomyces sp. US24 strain. Research in Microbiology, 154: 345-352. https://doi.org/10.1016/S0923-2508(03)00077-9

Nakaew N., Pathom-aree W. \& Lumyong S., 2009 Generic diversity of rare Actinomycetes from Thai cave soils and their possible use as new bioactive compounds. Actinomycetologica, 23: 21-26.

https://doi.org/10.3209/saj.SAJ230201

Nimaichand S., Devi A.M., Tamreihao K., Ningthoujam D.S. \& Li W.J., 2015 - Actinobacterial diversity in limestone deposit sites in Hundung, Manipur (India) and their antimicrobial activities. Frontiers in Microbiology, 6: 413. https://doi.org/10.3389/fmicb.2015.00413

Niyomvong N., Pathom-aree W., Thamchaipenet A. \& Duangmal K., 2012 - Actinomycetes from tropical limestone caves. Chiang Mai Journal of Science, 39: 373-388.

Olson E.H., 1968 - Actinomycetes isolation agar. In: Difco: supplementary literature. Difco Laboratories, Detroit, Michigan.

Ouhdouch Y., Barakate M. \& Finance C., 2001 Actinomycetes of Moroccan habitats: isolation and screening for antifungal activities. European Journal of Soil Biology, 37: 69-74.

https://doi.org/10.1016/S1164-5563(01)01069-X
Petit P., Lucas E.M.F., Breu L.M.A., Flenning L.H.P. \& Takahashi J.A., 2009 - Novel antimicrobial secondary metabolites from a Penicillium sp. isolated from Brazilian cerrado soil. Electronic Journal of Biotechnology, 12: 1-9. https://doi.org/10.2225/vol12-issue4-fultext-9

Ramesh S., Rajesh M. \& Mathivanan N., 2009 Characterization of a thermostable alkaline protease produced by marine Streptomyces fungicidicus MML1614. Bioprocess and Biosystems Engineering, 32: $791-800$,

https://doi.org/10.1007/s00449-009-0305-1

Rancic A., Sokovic M., Karioti A., Vukojevic J. \& Skaltsa H., 2006 - Isolation and structural elucidation of two secondary metabolites from the filamentous fungus Penicillium ochrochloron with antimicrobial activity. Environmental Toxicology and Pharmacology, 22: 80-84. https://doi.org/10.1016/j.etap.2005.12.003

Romano G., Costantini M., Sansone C., Lauritano C., Ruocco N. \& Ianora A., 2017 - Marine microorganisms as a promising and sustainable source of bioactive molecules. Marine Environmental Research, 128: 58-69. https://doi.org/10.1016/j.marenvres.2016.05.002

Romero C., Medina E., Mateo M.A. \& Brenes M., 2017 - Quantification of bioactive compounds in Picual and Arbequina olive leaves and fruit. Journal of the Science of Food and Agriculture, 97: 1725-1732.

https://doi.org/10.1002/jsfa.7920

Romero C., Medina E., Mateo M.A. \& Brenes M., 2018 New by-products rich in bioactive substances from the olive oil mill processing. Journal of the Science of Food and Agriculture, 98: 225-230.

https://doi.org/10.1002/jsfa.8460

Rong X., Guo Y. \& Huang Y., 2009 - Proposal to reclassify the Streptomyces albidoflavus clade on the basis of multilocus sequence analysis and DNADNA hybridization, and taxonomic elucidation of Streptomyces griseus subsp. solvifaciens. Systematic and Applied Microbiology, 32: 314-322. https://doi.org/10.1016/j.syapm.2009.05.003

Romanenko L.A., Uchino M., Kalinovskaya N.I. \& Mikhailov V.V., 2008 - Isolation, phylogenetic analysis and screening of marine mollusc-associated bacteria for antimicrobial, hemolytic and surface activities. Microbiological Research, 163: 633-644. https://doi.org/10.1016/j.micres.2006.10.001

Rule D. \& Cheeptham N., 2013 - The effects of UV light on the antimicrobial activities of cave actinomycetes. International Journal of Speleology, 42: 147-153. https://doi.org/10.5038/1827-806X.42.2.7

Saiz-Jimenez C., Cuezva S., Jurado V., FernandezCortes A., Porca E., Benavente D., Cañaveras J.C. \& SanchezMoral S., 2011 - Paleolithic art in peril: policy and science collide at Altamira Cave. Science, 334: 42-43. https://doi.org/10.1126/science.1206788

Sánchez Márquez S., Bills G.F., Zabalgogeazcoa I., 2011 - Fungal species diversity in juvenile and adult leaves of Eucaliptus globulus from plantations affected by Mycosphaerella leaf disease. Annals of Applied Biology, 158: 177-187.

https://doi.org/10.1111/j.1744-7348.2010.00449.x

Shirling E.B. \& Gottlieb D., 1966 - Methods for characterization of Streptomyces species. International Journal of Systematic Bacteriology, 16: 313-340. https://doi.org/10.1099/00207713-16-3-313

Singleton P., 1999 - Bacteria in Biology, Bacteriology and Medicine. Wiley Chichester, UK, p. 444-454.

Stomeo F., Portillo M.C., Gonzalez J.M., Laiz L. \& Saiz-Jimenez C., 2008 - Pseudonocardia in white colonizations in two caves with Paleolithic paintings. 
International Biodeterioration \& Biodegradation, 62 : 483-486.

https://doi.org/10.1016/j.ibiod.2007.12.011

Subramani R. \& Aalbersberg W., 2013 - Culturable rare Actinomycetes: diversity, isolation and marine natural product discovery. Applied Microbiology and Biotechnology, 97: 9291-9321.

https://doi.org/10.1007/s00253-013-5229-7

Takizawa M., Colwell R.R. \& Hill R.T., 1993 - Isolation and diversity of actinomycetes in the Chesapeake Bay. Applied and Environmental Microbiology, 59: 997-1002.

Vanderwolf K.J., Malloch D., Mcalpine D.F. \& Forbes G.J., 2013 - A world review of fungi, yeasts, and slime molds in caves. International Journal of Speleology, 42: 77-96.

https://doi.org/10.5038/1827-806X.42.1.9

White T.J., Bruns T., Lee S. \& Taylor J., 1990 Amplification and direct sequencing of fungal ribosomal RNA genes for phylogenetics. In: Innis M.A., Gelfand D.H., Sninsky J.J. \& White T.J. (Eds.), PCR protocols, a guide to methods and applications. Academic Press, San Diego, p. 315-322.

Williams S.T. \& Davies F.L., 1965 - Use of antibiotics for selective isolation and enumeration of actinomycetes from soil. Journal of General Microbiology, 38: 251-261. https://doi.org/10.1099/00221287-38-2-251 